\title{
CURRICULUM INTEGRATION AS TREATY PRAXIS
}

\author{
DEBORAH FRASER ${ }^{1}$ AND HOKIMATE PARAHA ${ }^{2}$ \\ 1 Department of Human Development and Counselling, The University of Waikato \\ 2. Richmond Park School
}

\section{INTRODUCTION}

Te manu ka kai i te miro, nona te ngahere.

Te manu ka kai i te maatauranga, noona te ao.

The bird that feeds on the miro owns the forest.

The bird that feeds on knowledge owns the world.

Curriculum integration is a curriculum design theory that promotes the integration of self and social interests, school and societal issues, and human experience with discipline knowledge. The curriculum is organised around significant problems and issues that emerge within an atmosphere of enquiry. These problems and issues (which form the basis of investigations) are collaboratively posed, refined, and explored by teachers and students in concert (Beane, 1997). In many respects it is one of the most misunderstood educational theories with critics dismissing it as a fad of the 1980s, or a watering down of 'real' curriculum through superficial thematic studies. Therefore, resistance to curriculum integration has largely stemmed from misinterpretation but also from the challenge it presents to teachers and administrators, an issue that will be examined further here.

The purpose of this paper is to convey how curriculum integration promotes the principles of the Treaty of Waitangi (the document signed in 1840 between the Crown and Māori that forms the basis of partnership in Aotearoa New Zealand). In doing so we argue that this curriculum design theory, while relevant for all students, can be particularly suitable for Māori given its cultural responsiveness. Some of the difficulties and tensions associated with curriculum integration are discussed and, finally, a case study is presented to show curriculum integration in practice. Space does not permit an analysis of the confusions surrounding interpretations of curriculum integration, nor the origins of this design (for an examination of these issues see Beane, 1997 and Fraser, 2000). Suffice to say that curriculum integration has its roots in the progressive education movement and has been advocated by great philosophers and educators (such as John Dewey) for nearly a century.

Advocates of curriculum integration have made various claims about the merits of curriculum integration. This literature asserts that it:

- $\quad$ Provides a meaningful curriculum;

- Ensures that power and decision making is shared between teachers and students;

- Helps students link discipline knowledge;

- Promotes student independence and interdependence;

- Makes maximum use of teaching time; 
- Draws upon issues of global, social, and personal significance to students;

- $\quad$ Provides an inclusive and differentiated curriculum;

and many other positive processes and outcomes (Beane, 1997; Boomer, Lester, Oncore \& Cook, 1992; Costa, 2002; Fraser \& Charteris, 1998; National Schools Network, 1998; Stewart \& Nolan, 1992; Thornley \& Graham, 1998). In the hands of talented teachers, such a curriculum design engages students in deep level learning which has lasting effects on their views of the world and their views of themselves as capable learners.

Curriculum integration (hereafter referred to as CI) also provides a view of learning and teaching that corresponds with some of the key principles that underpin the Treaty of Waitangi. This close articulation between the Treaty and CI encourages a pedagogy that is philosophically aligned with te ao Māori (the Māori world). Such congruence enables Māori to teach and to learn in ways that are culturally appropriate. Moreover, as the whakatauki above asserts, CI expands learners' options and pushes the boundaries of knowledge. It is acknowledged that generalisations about how Māori might learn best are fraught, given that essentialist views of any culture say more about outside observers than they do about the reality of those being 'analysed'. Therefore, this paper adds the caveat that the ideas expressed here will not necessarily hold for different hapu or iwi, let alone for all Māori. However, it is the principles examined in this paper that may have direct relevance for those who know and appreciate te ao Māori and work with Māori students.

\section{THE NEED FOR POWER SHARING}

The Treaty is presented as a metaphor for power sharing in Bishop and Glynn (1999) who emphasised how the three articles of the Treaty (partnership, protection and participation) can be used for planning and evaluating educational activities in schools. Such a model presents a number of challenges that cut to the heart of education, for example, whose experiences are validated in the classroom?, who defines what is legitimate knowledge?, and who determines what is 'appropriate' participation and achievement for Māori? By asking these questions we start to wrestle with how to create a truly negotiated and dynamic partnership - one that avoids lip service and superficial responses. When teachers co-create relationships of partnership, protection and participation with their students, they communicate their respect for students' tino Rangatiratanga:

In other words...contexts are created where learners can safely bring what they know and who they are into the learning relationship. In such settings teachers and community interact and home and school aspirations are complementary. Further, what students know, who they are, and how they know what they know, forms the foundation of interaction patterns in the classroom. In short, culture counts. (Bishop, 2001, p. 209)

It can be argued, however, that little in education truly emulates the negotiated process that such a partnership requires, if it is to be sustained over time. Negotiating the curriculum with students provides a partnership in power sharing which can benefit all. In particular, Māori students gain educationally when they are given the opportunities to take charge of their learning in ways that engage 
their interest, acknowledge their culture, and model power sharing (Bishop, 2001; Bishop \& Glynn, 1999; Macfarlane, 2000; Smith, 1999). With the guidance of a skilled teacher, the processes involved in CI enable students to take increasing responsibility for their learning.

\section{Using Power, Not Sharing Power: Mixed and Confusing Messages}

Many of us as teachers would agree that negotiating curriculum with students is a pedagogically sound practice that involves students as active participants and, therefore, conveys respect for many of the things our students contribute. However, some of the structures and expectations of schooling (and higher education) can thwart attempts at power sharing. School implementation plans can constrain what is taught and how it is taught. Course outlines in higher education are expected to prescribe in advance the topics to be covered and the forms of assessment. There is little, if any, room for negotiating curriculum in such settings. Moreover, teachers sometimes feel that they are already sharing power with their students. Some of the more common forms of 'negotiation' that teachers employ are:

- $\quad$ Basing their units of work on students' interests;

- $\quad$ Encouraging students to bring relevant material to school;

- $\quad$ Giving students choices about the order in which activities are completed;

- Involving students in constructing criteria for assessment

While these are generally sound practises, there is much more to the power sharing process that is embodied in CI (see for example, Beane, 1997; Beane, Ellsworth \& Miller, 1996; Boomer et al., 1992; Brodhagen, 1995). What often happens is that teachers plan most units in advance and consult with students on a few minor and peripheral details. The core elements, activities, and direction of such units remain unchanged.

Sharing power in the classroom is difficult for some teachers who experience discomfort when abdicating their prominent role as decision-maker. Planning units, organising activities, and deciding on assessment tasks is (for the most part) diligently and professionally undertaken by teachers with considerable regard for curriculum objectives. Sincere attempts are often made to choose 'popular' topics that will excite and motivate students. Topics used in previous years and considered successful are often recycled by teachers with subsequent classes. Beane (1997) has also noted that appealing topics comprise the fare of many teachers' units. However, the effort involved in negotiating learning with students means that teaching cannot be fully planned in advance. In contrast to resource units that prescribe content, teachers have to take cognisance of their students' questions and prior knowledge which could mean abandoning some of their own ideas and habits of planning. One senior primary teacher commented in a professional development programme on curriculum integration, "This challenges my effectiveness as a teacher. I lose some 'control' - an issue to deal with. Planning is less specific [I] can feel threatened... Have to learn how to plan with children - be more divergent and flexible" (Fraser \& Whyte, 1999, p. 28).

Teaching (like life) is fraught with paradox and while we may espouse certain ideals, some of our practices can run counter to these goals. For example, we may advertise as a "learner centred school" yet have most decisions in the school made by adults. We may believe that learning should be meaningful for 
students yet we teach some things without clarifying the purposes or developing relevant contexts. We may encourage the ideas of students but continue with our plans, our activities, and our forms of assessment, unchanged in the light of student feedback. This is not to say that teachers should abdicate planning or assessing. Quite the opposite. Planning, teaching, and assessment by the teacher are essential if $\mathrm{CI}$ is to provide a deep-level learning experience for students. However, the planning, teaching and assessment is more focused and more responsive to students as a result of negotiating with them during investigations or units of work. Therefore, it cannot all be determined in advance.

The list below provides examples of the widely recognised contradictions that can emerge between the goals we have for students and the practices we may employ:

\section{Goal}

Negotiating learning

Responsibility

Linking knowledge

\section{Contradictory Practices}

Teachers devise detailed unit plans with their syndicate in advance. Some minor amendments are made later.

Students get to choose the order in which they complete activities the teacher has organised.

School programme is rigidly modularised in advance.

Assessment driven teaching dominates which is based on observable behaviours, checklists and specific teacher-chosen objectives.

Teachers plan and organise all activities for students to complete.

Teachers ring bells or clap hands to signal when to change from one activity to the next.

Teachers make all the decisions on grouping for classroom management purposes.

Teachers teach to separate curriculum objectives rather than incorporate objectives across more than one discipline that naturally coincide.

Students do activities from a range of curriculum areas determined by the teacher around a central theme like 'plastics'.

Teachers and students do not draw upon past learning to inform present investigations: Once a unit is over it is considered finished. 
Such contradictions and mis-matches provide considerable challenges when engaging teachers in professional development in CI. The processes involved in $\mathrm{CI}$ are demanding, and complex yet can be highly rewarding for both teachers and students. However, the effort required to change one's practice can be considerable and resistance can readily emerge (Fullan, 1999; Hargreaves \& Evans, 1997). It is understandable that a number of teachers are reluctant to alter a 'system' they have honed and polished over many years and which produces results for some students. However, a few teachers (especially those in low SES or low decile areas) quickly realise the significance of CI for the students they teach (Fraser \& Whyte, 1999). For example, one high school teacher wryly commented on the transmission-teaching method (with little, if any student negotiation) in her multicultural school, "Most of what I teach is not relevant to my kids" (personal communication, 1998).

This teacher honestly recognised the mis-match between the material she taught her students, how she taught it, and what her students needed. This mismatch is exacerbated by cultural differences. Similarly, Nuthall and Alton-Lee (1997) stated that:

Some students have to learn to live in two cultures: the culture of their home and friends, and the culture of the teacher. Other students need only live in one culture because their home and friends share the culture of the teacher. For some students who live in two cultures, succeeding in the classroom is often very difficult. The teacher uses hidden meanings, makes assumptions, and implies things that they cannot understand. (p. 8)

The change required for some teachers is considerable when they attempt to bridge the divide between their own and their students' cultures. Such a change is initiated when teachers firstly understand that such cultural mis-matches can occur. Secondly, if this is the case, teachers need to appreciate, understand, and connect with their students' cultures, not regard theirs as somehow 'deficit'. "Simply put, if the imagery we hold of Māori students (or indeed of any students) is one of deficits, then our principles and practices will reflect this, and we will thereby perpetuate the educational crisis for Māori students" (Bishop, 2001, p. 215).

Sharing power with students is a highly skilled process which starts with classroom climate in order to create 'power alongside' rather than 'power over' students (Peters, 1966).

\section{The Teacher's Role in Power Sharing}

The effort required for $\mathrm{CI}$ can seem rather extreme given the resourcefulness, research, flexibility, and sheer hard work required. But if students are to have the challenging curriculum they deserve, if they are to be both extended and motivated on a daily basis to grow beyond expectations, and if they are to experience a curriculum that takes 'who they are' seriously, then teachers must move beyond 'what suffices' to 'what makes a difference'. Moreover, if Māori students are to be actively engaged as real participants in what is taught and how it is taught, then they deserve a curriculum that respects who they are and what they bring to the classroom. From here, teachers can build knowledge and skills with students in ways that are culturally congruent and educationally powerful. It 
is well established that the school curriculum reflects a largely Pakeha view of the world although Māori versions of various curriculum documents have provided much needed alternatives. Nonetheless, for those Māori students in regular schools (not immersion Māori language settings or bilingual schools), the chances of experiencing a culturally relevant curriculum can be small. That is not to say that some teachers and schools have not made great efforts to ensure cultural relevance in the school curriculum for Māori. It is just that, generally, this is less likely to occur in Pakeha dominated settings given systemic issues, dominant values, and hegemonic processes.

In sharing the power, teachers are thrust into the role of researchers and investigators with their students and this can cause anxiety. This is not to say that teachers learn alongside their students at every stage. Teachers also need content knowledge so that they can most effectively scaffold children's thinking as a result of knowing what to aim towards. When teachers are out of their depth with the knowledge base required in certain topics, their questioning and scaffolding can become shaky, superficial, and aimless. It is little wonder then, that a number of teachers experience discomfort when negotiating curriculum with students. It becomes readily apparent that the depth of questioning required is contingent upon pedagogical skill and subject knowledge. As Snook (1992), Fraser and Spiller (2001), and Ramsay and Oliver (1994) remind us, teachers' knowledge remains crucial to effective pedagogy. In addition to content knowledge, teachers need to know about how to question students and scaffold their thinking to develop students' learning most effectively. They need to assist students with the direction of their investigations and the particular skills they will require. This crucial pedagogical skill is frequently commented on. For example, a participant in a professional development contract stated, "I worked on helping the children to refine their questions but they had difficulty with developing direction for their questions - what they were going to do to investigate their issue" (Fraser \& Whyte, 1999, p. 28).

Scaffolding is also required when teachers assist students with necessary research skills. Sending students to the library, even very able students, to investigate a topic is not enough to sharpen their research abilities. Teacher modelling and scaffolding takes place at many points during $\mathrm{CI}$ and teachers must explicitly teach the skills that students require to extend their learning. It is the teaching of both skills and content that supports students' depth of learning. Moreover, the skills have direct relevance as they are taught in contexts that are meaningful around issues that students have identified and refined. Students' participation in the learning process means that they see the purpose for certain skills and genuinely want to know how to access the information they require. Of course $\mathrm{CI}$ is more than just the teaching of skills to access information. This is merely a part of the learning that is encouraged through this approach. CI crucially enables the development of attitudes, values, and critical thinking. The case study outlined later includes some examples of this wider dimension.

Responsiveness to students' needs and interests is essential when teachers draw upon issues that concern and affect students. Students' readiness is ascertained through ongoing assessments that determine which skills need to be taught and the timing of such teaching to ensure students' engagement. The focus on issues that concern students ensures that teachers respect and acknowledge students, drawing upon students' cultural capital to develop meaningful curriculum experiences. For example, William Pua taught high school economics in South Auckland. He incorporated elements of Pacific rap culture to teach the 
concepts of economics to his predominantly Pacific Island students (see Pua, 1998). By drawing upon this culture in his teaching Pua was able to cover the required curriculum through a vehicle which had high interest and relevance to the lives of the young people he taught. He argued that the influence of hip hop/rap culture on Pasifika youth is often overlooked yet it has a strong influence on his students' language, attitudes, fashions and psyche. Furthermore, by acknowledging Pacific rap culture he was acknowledging what was valued by his students in a way that conveyed respect for their lives and their evolving identities as Pasifika people. The work of Pua and other inspirational teachers highlights the importance of a culturally relevant curriculum. This issue in respect to Māori culture is discussed next.

\section{CULTURAL RELEVANCE}

The concept of a culturally relevant pedagogy (Bishop \& Glynn, 1999; LadsonBillings, 1994) articulates smoothly with CI. When teachers take the personal concerns of students seriously and examine social issues with them that are drawn from the students' cultural positionings, they are acknowledging who students are, what they bring to the classroom, and how their interactions with others influence their thinking. They are acknowledging students' ethnicity, culture, class, ability, disability, gender and so forth. When our experience and identity are recognised as central and significant to the learning process, we are more likely to be regarded as a participant, capable of active decision-making rather than as a passive object, to be decided about and judged (Hooks, 1994). Moreover, teachers who teach in this way regard knowledge as a social construction. They realise that knowledge is not static and unchanging but can be "continuously re-created, recycled, and shared" with students (Ladson-Billings, 1994, p. 81). This perspective views curriculum "as an organic, human knowledge construct, that helps learners make sense of their personal and social worlds and enables them to live and grow effectively as informed, active participants of society" (Fraser \& Whyte, 1999, p. $31)$.

For teachers in Kura Kaupapa Māori or immersion classes (where the language of instruction is Māori) cultural relevance begins with the protocols of Māori culture - powhiri (formal welcome onto marae or meeting place), karakia (prayers), whakapapa (genealogy), mihimihi (greeting and introduction), and so forth, which are integral parts of the school and/or class curriculum. Students in immersion contexts learn these protocols and when and how it is appropriate to use them. Oral language, communication, history and ritual are all learnt and practised within the school, creating an important connection with community and tribal culture. Sometimes, however, classroom practices and pedagogy can revert to transmission models of teaching revealing 'power over' rather than 'power alongside' philosophies. There is a tendency also to assume that group work is the panacea for Māori students yet research in this area thus far indicates that group settings that allow for individual agency alongside dyadic and group interactions provide equally beneficial learning environments (e.g., Hohepa, McNaughton \& Jenkins, 1996). When considering what 'works' for Māori students therefore, we need to avoid simplistic generalisations and search for the nuances, dimensions and processes that enhance their learning. 


\section{POWER SHARING IN PRACTICE}

$\mathrm{CI}$ and the pedagogy required to sustain it, has the complexity and nuance sufficient to enhance the learning of all students. Within the practice and design of CI, students' culture is acknowledged and drawn upon when considering what to study and how to learn. Moreover, CI is more in keeping with te ao Māori as knowledge is not compartmentalised in discrete categories.

The following sections outline CI in practice in an immersion Māori class of 13 six to ten year olds. The class was part of a decile 1 full primary school. The kaiako (teacher) was Hokimate Paraha, the co-author, who had a bilingual teacher education degree plus a Rumaki qualification for those teaching in Māori immersion settings. She encouraged students' responsibility for their learning and taught them the skills they needed to raise issues, access information and deepen their understanding. Throughout her pedagogy she modelled her willingness to share power and decision making.

\section{Maui Stories}

The children showed considerable interest in the Maui stories that Hokimate was sharing with the class. These included Maui and his father, Maui and the dog, Maui's fishing and Maui slowing down the sun. The children's responses to these stories revealed to their teacher that some of them had difficulty with asking questions. This is a crucial skill in $\mathrm{CI}$ and questioning often needs to be taught. Teaching questioning skills includes identifying what makes a 'good' question, the difference between open and closed questions, refining questions and building on other people's questions. The six and seven year olds had difficulty differentiating between the meaning of certain questions. In particular, they were confused with the difference between who did? who will? when did? and when will? Two weeks was spent with these children clarifying the difference in semantics and practising the correct usage.

As the children explored the stories further they decided they would like to re-tell on video the story of Maui slowing the sun. At first they drew all the characters they would need for the video production. Three of the older children in the class realised that the drawings restricted their re-telling of the story as the cardboard cut-outs were inadequate for conveying emotion! These three suggested that the children themselves become the actors and the rest of the class agreed. Being tuakana (status of respected elder brothers/sisters), these children had influence and mana in the class.

The children had to script the story for video-taping and their teacher taught them a range of key camera shots. These included face only (te kanohi anake), all of the body (ko te tinana katoa), and scenery (te wahi). Costumes were made and worn by the 'actors' and the re-enactment was caught on video-tape by some of the other children who became the technicians, director, and producers.

\section{The Black Boat}

At the completion of the Maui video, the children started talking in an animated fashion about the 'black boat' (Black Magic) which at the time, was racing on the Hauraki Gulf for the America's Cup. A considerable number of questions were raised by the children and these became more focused and refined as the study progressed. Their questions included: 
- Why don't they put a motor on the boat whaea? (an early question!)

- How does the boat go so fast?

- Why is the race held in Auckland?

- Who builds the boats?

- Who organised the race?

- Where did we win the previous America's Cup?

- Why are there two cups?

- What is a challenger?

After some group work on the internet, the children located a plethora of information about the America's Cup and their teacher challenged them to match their questions to their information to further their understanding. While some of this information answered their questions, it also raised more questions. Locating 'answers' to their initial questions was just the first step in the process. The children's investigations took them further and deeper into the topic. They decided they would like to visit the cup village. This required a phone call to the America's Cup village to check race times and days. The teacher taught the children how to introduce themselves on the telephone and how to ask for what you need. She also gave them in-class practice before they phoned through.

The next step was to ask permission from the school's principal. A group of three boys were nominated to approach the principal and they had to overcome their whakama (shyness) in order to approach her. These children had not asked their principal for a 'favour' before and were not accustomed to asking requests of adults of high status. However, rather nervously but with determination, they made an appointment with their principal who invited them into her office and asked for an outline of their plans for the day. Once they secured permission, another group of three children (two girls and one boy) asked the school secretary for the telephone book and the numbers she uses for ordering buses. Their job, with the guidance of their teacher, was to ring a range of bus companies to check costs and availability. This task reinforced the telephone skills taught earlier and had a clear purpose for use. The children wanted 'half' a bus for their small class. They came to an arrangement with one company because it provided a good price but also because the woman they spoke with said they could change their booking if for some reason a race was postponed. They were intrigued by one man who refused to take a booking from children, even when he spoke with their teacher as well.

The children attended the final race and were quite a hit with the supporters of the Italian team. Prada's supporters were dancing on the dock and the children started copying them. Before the children knew it, they were lifted onto the Italians' shoulders showing that the language of emotion and dance can bridge verbal barriers.

The children's enthusiasm for the topic continued on return and they furthered their knowledge through:

- locating Italy on a world map

- locating all the competitors' countries

- $\quad$ identifying the many islands of the Hauraki gulf

- developing map skills and greater geographical knowledge 
They also commented on the tension, excitement, expectation and skill required to be the best in such a competitive sport. The youngest child in the class was impressed with everyone's red socks and was surprised that the boat was bigger than he anticipated!

\section{Gondwanaland}

At some stage during the map reading work, a comment was made about how countries were formed. This also harked back to the earlier Maui stories and the tale of Maui fishing up the North Island (Te ika a Maui). By now the children were familiar with question asking and keenly involved themselves in the pursuit of knowledge. After watching two videos (an activity of choice during class time) the concept of Gondwanaland intrigued a number of them and they wanted to know how scientists came up with these ideas. They also wanted to know:

- How do scientists know how old things are?

- Where do you find dinosaur bones?

- How do you find them?

- Where does the money come from to dig up the bones?

- How are the bones joined together?

- Why don't bones rot?

- What is DNA?

As they had done before, with the guidance of their teacher, the children organised a trip to investigate their topic. This time they headed to the University of Waikato to visit an expert (Dr Miles Barker) who could help them with their queries. Again, they were involved in practising telephone and fax skills (different children from last time took responsibility for this task) and preparing transport. They also had to clarify their questions (some worked in pairs) before faxing them to Dr Barker prior to their visit. During their visit their level of interest was readily apparent. Their questions provided them with a focussed starting point and led to discussions that prompted the clarification of ideas and concepts. Dr Barker commented:

It is important for Rumaki children to understand why there is more than one account of how New Zealand came to be. They have learnt the tale of Maui fishing the land from the sea, but also the theory of Gondwanaland. So they can find out if these theories are in conflict or if they are saying the same thing, but from a different angle. (Students view, 2000, p. 8)

The university visit helped the children to understand the complementary nature of these theories and in doing so, honour both their cultural beliefs and the theories of 'western' science. Furthermore, this experience revealed the teacher's ability to promote her students' responsibility for organising the trip, developing questions, interacting with an 'expert', refining their ideas and connecting concepts in ways that deepened their understanding. Dr Barker had dinosaur fossils for the children to view which prompted many more queries. He pointed out that, "it is important to encourage a style of learning where the children can see and touch and ask questions rather than just sitting there listening to the teacher tell them everything" (Students view, 2000, p. 8). 
Teaching through the philosophy and practice of CI requires commitment and perseverance yet, in our experience, the learning gains more than compensate. The sophistication of the children's questions improved with each topic and this was complemented by a growth in responsibility as they developed the skills necessary to deepen their understanding. And as the children's knowledge and ability grew the teacher had to adjust and extend what she taught in order to provide the challenge her children needed and wanted.

Like many teachers, however, Hokimate was sceptical of $\mathrm{CI}$ at the outset:

I thought it would be too woolly when I started. I had hard children, street-wise and all that sort of thing. But [through using $\mathrm{CI}$ ] they made good choices that I didn't think they could - that showed me where they're at and they went beyond where I thought they were. What's more, the children realised they have abilities...I also became more involved in teaching children the skills they needed - telephone skills, questioning - all became more specific. (Fraser, 1999, p. 8)

She also noted that her students took greater control of accessing information:

Our library times changed because of the focus on what they wanted to find out. They would say "Whaea, we need to go to the library!" We couldn't find all they needed in our school library so they wrote to their parents to ask if they could go to the main library in town after school. Eight children were given permission to go on a regular basis - these are children who had previously never been to a library outside school. (Fraser, 1999, p. 8)

CI depends upon the development of a learning context within the classroom that is characterised by negotiation, power sharing and investigation. The ability to question, therefore, is crucial for both teachers and students. The students in this class became so adept at questioning that it influenced their behaviour at home. For some parents this created some discomfort as they weren't accustomed to their children questioning them so rigorously and felt awkward about not knowing all the answers. Indeed, this awakening of students' questions is often challenging to teachers as well. However, this fear of not knowing and losing control must be addressed by offering teachers ways to express and address these concerns so that they are not caught in a paralysis of inaction (Hargreaves \& Fullan, 1998). When teachers feel doubtful, threatened or cynical they are likely to retreat to previous ways of operating in order to restore a sense of security and familiarity (Fullan, 2001; Joyce \& Showers, 1988). Teachers can be encouraged to transform classroom settings with students wherein learning experiences are inclusive and learning approximates that which is needed in life. The power regarding what constitutes process and product in such classrooms is collaboratively negotiated.

In terms of the traditional cultural concept of 'not questioning one's elders' one may question the cultural appropriateness of this practice for Māori students (Papakura, 1986). However, the students in this class quickly learnt when to 'draw the line' in terms of respect for elders, especially with grandparents, but this did not mean that they curtailed questioning them. They learnt how to do this appropriately and respectfully as a result of their classroom experience and the teacher's encouragement. For example, at the students' request, three 
grandparents also visited the class to willingly answer questions and discuss issues related to their own schooling.

Traditional Māori norms are not necessarily contested through CI. The wharenui (meeting house) is a place where ideas are shared and debated and questions are raised. This tradition gives license for students to question elders in ways that are culturally congruent. CI ensures that meaningful connections are made between Māori students' lives and the curriculum. As Bishop and Glynn (1999) argued:

...whatever the approach taken to curriculum integration, there needs to be an assurance that neither the curriculum content nor the pedagogical method preclude the development of collaborative learning partnerships which respond to the specific cultural needs and interests of the learner. (p. 194)

\section{CONCLUSION}

It has been argued that the improvement of students' learning is inextricably linked to the improvement of teaching (e.g., Darling-Hammond, 1998; Joyce \& Showers, 1988). CI promotes a pedagogy that is culturally responsive, challenging, and engaging (Beane, 1997; Bishop \& Glynn, 1999). This approach to teaching and curriculum brings teachers closer to understanding how students learn, and how much they can learn. Moreover, the articles of the Treaty are brought to life through the democratic processes that underpin CI: Māori students can take an active part in co-constructing curriculum, they can bring the authority of their culture and language to the classroom which is valued, and they can fully participate in the processes of learning.

\section{REFERENCES}

Beane, J. A., Ellsworth, E. A., \& Miller, J. L. (Producers). (1996). Doing curriculum integration. [video]. (Available from Wisconsin Department of Public Instruction, Drawer 179, Milwaukee, WI, 53293-0179)

Beane, J. A. (1997) Curriculum integration: Designing the core of democratic education. New York: Teachers College Press.

Bishop, R. (2001). Changing power relations in education: Kaupapa Māori messages for mainstream institutions. In C. McGee \& D. Fraser (Eds.), The professional practice of teaching $\left(2^{\text {nd }}\right.$ ed.) (pp. 201-219). Palmerston North: Dunmore Press.

Bishop, R., \& Glynn, T. (1999). Culture counts: Changing power relations in education. Palmerston North: Dunmore Press.

Boomer, G., Lester, N., Oncore, C., \& Cook, J. (Eds.). (1992). Negotiating the curriculum: Education for the 21st century. London: Falmer Press.

Brodhagen, B. (1995). The situation made us special. In M. Apple \& J. Beane (Eds.), Democratic schools (pp. 83-100). Alexandria, Virginia: ASCD.

Costa, A. (2002, June). Changing curriculum means changing your mind. Address to the $10^{\text {th }}$ International Conference on Thinking, Harrogate, UK.

Darling-Hammond, L. (1998). Teachers and teaching: Testing hypotheses from a National Commission Report. Educational Researcher, 27(1), 5-15.

Fraser, D. (2000). Curriculum integration: What it is and is not. SET: Research Information for Teachers (3), 34-37. 
Fraser, D. (1999, December). They keep asking questions and want to know more: Enhancing students' (and teachers') learning through curriculum integration. Paper presented at AARE/NZARE conference, Melbourne, Australia.

Fraser, D., \& Charteris, C. (1998, October). What is curriculum integration and why do teachers need to know? Paper presented at the New Zealand Teacher Education Conference, Hamilton, NZ.

Fraser, D., \& Spiller, D. (2001). Effective teachers. In C. McGee \& D. Fraser (Eds.), The professional practice of teaching ( $2^{\text {nd }}$ ed.) (pp. 67-84). Palmerston North: Dunmore Press.

Fraser, D., \& Whyte, B. (1999). Curriculum integration: Milestone Report Four. Report to the Ministry of Education: Wellington.

Fullan, M. (1999). Change forces: The sequel. London: Falmer.

Fullan, M. (2001). The new meaning of educational change. New York: Teachers College Press.

Hargreaves, A., \& Evans, R. (Eds.) (1997). Beyond educational reform: Bringing teachers back in. Buckingham: Open University Press.

Hargreaves, A., \& Fullan, M. (1998). What's worth fighting for in education? Buckingham: Open University Press.

Hohepa, M., McNaughton, S., \& Jenkins, K. (1996). Māori pedagogies and the roles of the individual. New Zealand Journal of Educational Studies, 31(1), 29-40.

Hooks, B. (1994). Teaching to transgress: Education as the practice of freedom. New York: Routledge.

Joyce, B., \& Showers, B. (1988). Student achievement through staff development. New York: Longman.

Ladson-Billings, G. (1994). The dreamkeepers: Successful teachers of African American children. San Francisco: Jossey-Bass.

Macfarlane, A. (2000). The value of Māori ecologies in special education. In D. Fraser, R. Moltzen \& K. Ryba (Eds.), Learners with special needs in Aotearoa New Zealand ( ${ }^{\text {nd }}$ ed.) (pp. 77-98). Palmerston North: Dunmore Press.

National Schools Network (1998). Integrated curriculum: Classroom materials for the middle years. Deakin West: ACSA.

Nuthall, G., \& Alton-Lee, A. (1997). Student learning in the classroom: Understanding teaching and learning project 3. Report to the Ministry of Education: Wellington.

Papakura, M. (1986). Makereti: The old-time Māori. Auckland: New Women's Press.

Peters, R. S. (1966). Ethics and education. London: George Allen \& Unwin.

Pua, W. P. (1998, October). Bone thugs ' $n$ ' harmony, Coconut cream and Pacific Island academic failure. Paper presented at the New Zealand Teacher Education Conference, Hamilton, New Zealand.

Ramsay, P., \& Oliver, D. (1994). Teacher quality - A case study approach. Paper presented at the 7th Annual International Congress for School Effectiveness and Improvement, Melbourne, Australia.

Smith, L. T. (1999). Decolonizing methodologies: Research and indigenous peoples. London: Zed Books.

Snook, I. (1992). Teacher education: A sympathetic appraisal. Paper presented at the New Zealand Teacher Education Conference, Auckland, New Zealand.

Stewart, D., \& Nolan, P. (1992). The middle school: Essential education for emerging adolescents. Palmerston North: ERDC Press.

Students view dinosaur poo! (2000, May 1). The Education Weekly, 4-8. 
Thornley, C., \& Graham, S. (1998, October). Integration as a curriculum process. Paper presented at the New Zealand Teacher Education Conference, Hamilton, New Zealand. 